\title{
Personality and Learning Styles towards the Practical-Based Approach
}

\author{
Halizah Awang, Ahmad Dollah, Yusmarwati Yusof, Nurfirdawati Muhammad Hanafi, and Nur Sofurah \\ Mohd Faiz
}

\begin{abstract}
An enduring question for educational research is the result of individual deviations in the efficacy of learning. The individual learning differences that have been much explored relate to differences in personality, learning styles, strategies and conceptions of learning. This article studies the personality and the learning style profile exhibited by students in a practical based approach of vocational courses. The relationship between personality and learning styles among students was assessed as the students got along through the curriculum. The analysis show that students are more oriented towards an active learning mode in a practical-based approach. Given a specific instruction, some people will learn more effectively than others due to their individual personality and learning styles. This study will help a vocational instructor and advisors to understand their students and to design instruction that can benefit students to accomplish a respectable performance in their learning process.
\end{abstract}

Index Terms-Learning styles, personality, practical-based approach.

\section{INTRODUCTION}

Learning approach has gotten considerable attention over the past several years. Learning approach has attracted strong advocates among learners looking for alternatives to traditional teaching methods. For many educators, there remain doubts about what learning approach is and how it differs from one advance to others. Students get into colleges with varied cultural and ethnic backgrounds that bring a differ personality and learning styles [1].

The ways that students go around accumulating data and rendering information can be surprisingly different. Students have different tastes and strengths in how they gather information and process the data. These tastes are sometimes concerned to as learning styles and are practiced to describe and help us understand the different ways in which different student discover.

\section{Challenges of Human CAPITAL DeVelopment}

Education affects every individual of a country, the general

Manuscript received November 23, 2015; revised June 2, 2016. This work was supported in part by Universiti Tun Hussein Onn Malaysia (UTHM); Grant U226.

Halizah Awang, Yusmarwati Yusof, Nurfirdawati Muhamad Hanafi, and Nur Sofurah Mohd Faiz are with the Universiti Tun Hussein Onn Malaysia, Malaysia (e-mail: halizah@uthm.edu.my, marwati@uthm.edu.my, nurfirda@uthm.edu.my, sofurah@uthm.edu.my).

Ahmad Dollah is with Kuala Kangsar Vocational Collage, Malaysia (e-mail: jasmy58@yahoo.com). consensus has been that there is a high positive relationship between the rise in educational expansion and economic development [2]. An integrated human capital should strengthen the entire education includes preschool, primary and secondary schools, tertiary and lifelong training [3]. The focal point of the development of education and training should be aimed for the betterment of the quality of human capital. The rationale behind human capital is based on three arguments: a) That a new generation must be given the appropriate parts of the knowledge which has already been articulated by previous generations. b) That a new generation should be taught how existing knowledge should be used to develop new products, to introduce new processes and production methods and social services. c) That person must be encouraged to develop entirely new ideas, products, processes and methods through creative approaches. Thus, the existing educational system demands to be beefed up to assure that every person is afforded the opportunity to play up their potential and talent [4], [5] According to Nik Abdul Majid [3] again, the development of curriculum, assessment methods and learning approach should make priority to enhance human capital inquisitive, has the ability to think critically and have entrepreneurship in accordance with Malaysia's efforts to reach a developed nation by having knowledgeable and skilled citizens.

\section{PERSONALITY TYPES}

Personality types is specified as a fairly fixed characteristic of an individual. It defines how an individual deals with new information and views situations [6], [7]. Jung [6] who wrote that what seems to be a random behaviour is in reality the effect of deviations in the way people choose to utilize their mental capacities. He noticed that people generally employ one of two mental functions that are taking in information, which he called perceiving, or organizing information and coming to conclusions, which he called judging.

Jung [6] also noted that, although everyone takes in information and makes decisions, some people prefer to do more taking in information (perceiving) and others prefer to do more decision making (judging). Finally, Jung observed, "Each person seems to be more energized by either the external world (extraversion) or the internal world (introversion)." What Jung called a person's psychological type consists of his or her preference in each category: 1) Extraversion (E) - Introversion (I) was described how people react and interact with the universe around them. Extraverts are "outward-turning" and tend to be action-oriented, enjoy more frequent social interaction, and feel excited after 
spending time with other people. Introverts are "inward-turning" and tend to be thought-oriented, enjoy deep and meaningful social interactions, and feel recharged after spending time alone. 2) Sensing (S) - Intuition (N) was described how people, gather information from the world around them. People spend some time sensing and intuiting depending on the situation. People who prefer sensing tend to pay a great deal of attention to reality, particularly for what they can learn from their own senses. They tend to focus on facts and details and enjoy getting hands-on experience. Those who prefer intuition, pay more attention to things like patterns and impressions. They enjoy thinking about the possibilities, imagining the future and abstract theories. 3) Thinking ( $\mathrm{T}$ ) - Feeling (F) was focus on how people make conclusion based on the information that they collected from their sensing or intuition functions. People who prefer thinking place a greater emphasis on facts and aim information. They incline to be coherent, logical and impersonal when weighing a decision. Those preferring feelings are more likely to consider the people and emotions when arriving at a conclusion. 4) Judging (J) - Perceiving (P) describes how people tend to trade to the external universe. Those who lean toward judging prefer structure and firm decisions. People who lean toward perceiving are more perceptive, flexible and adaptable.

\section{LEARNING STYLES}

Learning styles is such a characteristic cognitive, effective, and psychosocial behaviours that serve as relatively stable indicators of how learners perceive, interact with, and respond to the learning environment [8]. Learning styles are considered by many to be one factor of success in higher education. The Soloman-Felder [9] Model of learning styles incorporates most of the major approaches to understanding learning styles. Table I describes the scale of Index Learning Styles.

TABLE I: MODEL OF LEARNING STYLES

\begin{tabular}{|c|c|}
\hline $\begin{array}{l}\text { ACTIVE } \\
\text { Active learners learn by doing } \\
\text { something with information. They } \\
\text { prefer to process information by } \\
\text { talking about it and trying it out. }\end{array}$ & $\begin{array}{l}\text { REFLECTIVE } \\
\text { Reflective learners learn by thinking } \\
\text { about information. They prefer to } \\
\text { think things through and understand } \\
\text { things before acting. }\end{array}$ \\
\hline $\begin{array}{l}\text { SENSING } \\
\text { Sensing learners prefer to take in } \\
\text { information that is concrete and } \\
\text { practical. They are oriented towards } \\
\text { details, facts, and figures and prefer } \\
\text { to use proven procedures. They are } \\
\text { realistic and like practical } \\
\text { applications. }\end{array}$ & $\begin{array}{l}\text { INTUITIVE } \\
\text { Intuitive learners prefer to take in } \\
\text { information that is abstract, } \\
\text { original, and oriented towards } \\
\text { theory. They look at the big picture } \\
\text { and try to grasp overall patterns. } \\
\text { They like discovering possibilities } \\
\text { and relationships and working with } \\
\text { ideas. }\end{array}$ \\
\hline $\begin{array}{l}\text { VISUAL } \\
\text { Visual learners prefer visual } \\
\text { presentations of material - } \\
\text { diagrams, charts, graphs, pictures. }\end{array}$ & $\begin{array}{l}\text { VERBAL } \\
\text { Verbal learners prefer explanations } \\
\text { with words - both written and } \\
\text { spoken. }\end{array}$ \\
\hline $\begin{array}{l}\text { SEQUENTIAL } \\
\text { Sequential learners prefer to } \\
\text { organize information in a linear, } \\
\text { orderly fashion. They learn in } \\
\text { logically sequenced steps and work } \\
\text { with information in an organized } \\
\text { and systematic way. }\end{array}$ & $\begin{array}{l}\text { GLOBAL } \\
\text { Global learners prefer to organize } \\
\text { information more holistically and in } \\
\text { a seemingly random manner without } \\
\text { seeing connections. They often } \\
\text { appear scattered and disorganised in } \\
\text { their thinking yet often arrive at a } \\
\text { creative or correct end product. }\end{array}$ \\
\hline
\end{tabular}

\section{The RelationshiP BETWEen PERSONALITY AND LEARNING}

Personality types and learning trades are thus interlaced with each other that personality shapes an important facet of getting a learning style. Learning strategies do not work on their own, but are directly dependent on the learner's learning style and other personality variables [10], [11]. In another study, a positive relationship between open and extroverted personality types and active-minded and responsive-intuitively learning styles was found. Specifically, a positive interdependent relationship was set up between the extraversion and active-cautiousness and openness and sensitive-intuitive features [12]. Kamarulzaman [13] examined the relationship between personality-learning styles in the related literature and added up to the conclusion that personality has effects on learning styles. He stated that extroverted individuals are particularly suited for accommodating learning style.

Therefore, to realize the intention, the field of technical and vocational education in detail is directly affected and need to transform into various fields including curriculum. The planning and growth of the curriculum should be thinking in a big frame so that the curriculum was guided by ideas which were developed on the creativity, innovation, flexibility and comfortable with change [14]. Mohamad [15] observed that efforts should be taken to acquire an education and training system that is efficient and responsive to meet the demands of the labour force that is versed and extremely skilled and equipped with positive values.

Nordin [14] suggests, skills and innovation, collaborate critical minded are very important in the planning and implementation of the educational system and curriculum in the future. Thus, according to Abdul Razak [16], an efficient education system should be provided to enhance students' achievement. Improving quality, access and equity in education should be continually strengthened. Vocational education system upgrading should be carried out carefully, including the execution of the new Standard Curriculum in Vocational Colleges (KSKV) was presented. Referable to the new KSKV system using a modular learning system, teaching and studying must also bring into account several factors, including personality types and different learning styles of students so that the process of teaching and learning could be implemented perfectly and give optimal benefits to students.

Thus, this study should be undertaken to identify the personality types and of learning styles as well as the relationship between the students personality and style of learning and its impact on vocational college students' excellence in order to benefit students, teachers, community and vocational institutions.

\section{Methodology}

A descriptive quantitative survey was applied to study the nature of the relationship between personality and learning styles towards vocational college students. The data were analysed to measure the relationship between two variables that describes the strength of the relationship and also the significance of the study. It conducted among students at the 
vocational college.

The study was conducted among 269 students from eight different types of courses, Vocational Diploma in Vocational College Malaysia. The sample of the study was taken from the courses of Automotive Technology, Electrical Technology, Business management, Bakery \& Pastry, Culinary, Cosmetology, Dressmaking \& Fashion and Early childhood studies.

An instrument used in this research was the Myers-Briggs Type Indicator (MBTI) and the Index of Learning Styles (ILS) to identify personality types and learning styles of respondent. A set of questionnaires was used as a tool to collect data on 269 students.

\section{DISCUSSION}

The result of the data obtained from the study was analysed using descriptive and inferential analysis method. Descriptive analysis in the form of frequency and percentage was used to discover personality types and dominant learning styles among students while the inferential analysis in the form of Spearman Correlation was used to assess the relationship between personality types and learning styles.

The findings related to personality in Table II, show that personality types Intuitive-Introvert-Thinking-Judging (INTJ) is the most popular which 27 people (11.2\%), followed by the personality Introvert -Intuitive-Feeling-Perceiving (INFP) 23 people (9.5\%), personality Introvert-Intuitive-Thinking-Perceiving (INTP) 21 people $(8.7 \%)$ and personality Extrovert-Sensing-Feeling-Judging (ESFJ) 19 people (7.9\%). ENTJ personality is a personification of the least favoured by students.

TABLE II: DISTRIBUTION OF FREQUENCY AND PERCENTAGES BY GENDER ON PERSONALITY TYPES

\begin{tabular}{ccc}
\hline Personality type & Frequency & Percentage $(\%)$ \\
\hline INTJ & 27 & 11.2 \\
INFP & 23 & 9.5 \\
INTP & 21 & 8.7 \\
ESFJ & 19 & 7.9 \\
ENFP & 18 & 7.5 \\
INFJ & 18 & 7.5 \\
ISFP & 18 & 7.5 \\
ISTJ & 16 & 6.6 \\
ISFJ & 15 & 6.2 \\
ESFP & 14 & 5.8 \\
ENTP & 12 & 5.0 \\
ENFJ & 11 & 4.6 \\
ESTP & 9 & 3.7 \\
ISTP & 8 & 3.3 \\
ESTJ & 7 & 2.9 \\
\hline
\end{tabular}

Overall, the student's preferred choice as in Table III, is a Visual learning style, 154 students (63.9\%) followed by learning style, balanced Sensing-Intuitive and balanced Sequential-Global -129 students (53.5\%). Learning style, Active (48.5\%) and learning style, Balanced Active-Reflective 109 students (45.2\%). While Intuitive learning style 31 students (12.9\%), Global learning styles 20 students $(8.3 \%)$, Reflective 15 students $(6.2 \%)$ and Verbal learning styles, 8 students $(3.3 \%)$ are an unpopular learning style in the teaching and learning process in vocational college. Summary of the findings shows a Visual learning style, balanced Sensing-Intuitive and balanced
Sequential-Global among vocational students has its advantages. Students can make themselves flexible during the process of teaching and learning, whether at the time with a teacher (face to face) or without a teacher (non-face to face) where students are able to explore the knowledge through observation, diagrams, illustrations or books reading to pursue theories as well as a concept.

TABLE III: FREQUENCY DISTRIBUTION ON LEARNING STYLES

$\begin{array}{lcc}\text { Learning style } & \text { Frequency } & \text { Percentage (\%) } \\ \text { Visual } & 154 & 63.9 \% \\ \text { Sensing-Intuitive } & 129 & 53.5 \% \\ \text { Sequential- Global } & 129 & 53.5 \% \\ \text { Active } & 117 & 48.5 \% \\ \text { Active-Reflective } & 109 & 45.2 \% \\ \text { Sequential } & 92 & 38.2 \% \\ \text { Sensing } & 81 & 33.6 \% \\ \text { Visual-Verbal } & 79 & 32.8 \% \\ \text { Intuitive } & 31 & 12.9 \% \\ \text { Global } & 20 & 8.3 \% \\ \text { Reflective } & 15 & 6.2 \% \\ \text { Verbal } & 8 & 3.3 \%\end{array}$

Table IV below shows the results of the significant relationship between personality and learning styles. The learning style Sensing-Intuitive with $p<$ in circumstances coefficient .05 is a very weak relationship $(r=0.307)$.

TABLE IV: RELATIONSHIP BETWEEN PERSONALITY AND LEARNING STYLES

\begin{tabular}{lcc}
\hline Learning style & $\begin{array}{c}\text { Sig } \\
\text { (2-sided) }\end{array}$ & Cramer V \\
\hline Active-Reflective & .281 & .266 \\
Sensing-Intuitive & .035 & .307 \\
Visual-Verbal & .877 & .210 \\
Sequential-Global & .422 & .253 \\
\hline
\end{tabular}

\section{CONCLUSION}

Overall, it was found that the majority of vocational college students has a personality of Introvert-Intuitive -Thinking-Judging-(INTJ), and main learning styles among vocational college students during the teaching and learning is Visual learning style. This means that vocational students prefer to learn using visual methods compared to other means.

Visual learning styles adopted by vocational college students actually have relevance to the field of disciplines in vocational colleges, especially in technical and hospitality where during learning process, they need to use the actual tools or other graphics such as diagrams, photos, videos, and animations. The use of actual machine and hand tools as teaching materials very helpful in teaching process. This indirectly led to the Visual learning style.

The next significant relationship exists solely between the personality and learning-style Sensing-Intuitive while others is not substantial. Therefore, teachers must ensure that teaching in the form of cognition and skills in vocational college would emphasize personality and learning style seriously so that students will be more interested in studying in vocational college.

When teachers and students understand the conflicts in their personality, teaching and learning styles, and therefore learning, is enhanced. A student's interests and learning approach directly affect how he or she performed. This was given to educators to consider different teaching approaches, based on the needs of students. 
Students whose preferences are different from those of a teacher may discover it difficult to adjust to the classroom atmosphere and the teaching methods of that teacher. Teachers who vary their teaching styles after learning about personality type often find they can motivate and teach a wider range of students, because they are developing diverse approaches that better meet the needs of all students.

\section{ACKNOWLEDGMENT}

This research was funded by Research Supporting Grant Scheme (RSGS; U226), from Universiti Tun Hussein Onn Malaysia and from the Ministry of Higher Education of Malaysia.

\section{REFERENCES}

[1] L. Bollinger, "The need for diversity in higher education," Acad Med., vol. 78, pp. 431-436, 2003.

[2] Y. O. Aluko and O. Aluko, "Human capital development: Nigeria's great challenge," Journal of sustainable development in Africa, vol. 13, no. 7, pp. 105-112, 2011.

[3] N. A. Majid, Penyediaan Rancangan Malaysia Kesepuluh, 2011-2015: Prospek Ekonomi Dan Hala Tuju Strategik, Unit Perancang Ekonomi, Putrajaya, 2009.

[4] J. B. Babalola, "Budget preparation and expenditure control in education," in Basic Text in Educational Planning, J. B. Babalola, Ed. Ibadan Awemark Industrial Printers, 2003.

[5] D. A. Olaniyan and T. Okemakinde, "Human capital theory: Implications for educational development," European Journal of Scientific Research, 2008.

[6] C. G. Jung, "Psychological types," Bollingen Series XX, Princeton, NJ: Princeton University Press, 1971.

[7] I. B. Myers, M. H. McCaulley, N. L. Quenk, and A. L. Hammer, MBTI manual: A Guide to the Development and Use of the Myers-Briggs Type Indicator, 3rd ed. Palo Alto, CA: Consulting Psychologists Press, 1998/2003.

[8] L. Curry, "Learning preferences in continuing medical education," Canadian Med Assoc J., vol. 124, pp. 535-536, 1981.

[9] F. M. Felder and B. A. Soloman, "Index of learning styles. North Carolina State University," MBTI Manual: A Guide to the Development and Use of the Myers-Briggs Type Indicator, 3rd ed. CA: Consulting Psychologists Press, 1998/2003.

[10] A. D. Cohen, "Second language learning and use strategies: Clarifying the issues," Symposium on Strategies of Language Learning and Use, December 13-16, 1996, Seville, Spain.

[11] N. Sadeghi, Z. M. Kasim, B. H. Tan, and F. S. Abdullah, Learning Styles, Personality Types and Reading Comprehension Performance, 2012.

[12] R. A. Sottilare, "Modeling the influences of personality preferences on the selection of instructional strategies in intelligent tutoring systems," Florida, University of Central Florida, 2006.
[13] W. Kamarulzaman, "Critical review on affect of personality on learning styles," in Proc. the 2nd International Conference on Arts, Social Science \& Technology, March 2012, Penang, Malaysia.

[14] A. B. Nordin, "Kurikulum Kearah Penghasilan Kemahiran Berfikiran Kritis, Kreatif dan Inovatif," JuKu: Jurnal Kurikulum \& Pengajaran Asia Pasifik, vol. 1, no. 1, Januari 2013.

[15] M. Mohamad, Rancangan Malaysia ke-8, 2001-2005, Jabatan Perdana Menteri, Putrajaya.

[16] M. N. A. Razak, Pelan Pembangunan Pendidikan Malaysia 2013-2025, Putrajaya, KPM, 2012

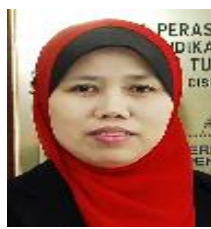

Halizah Awang received the $\mathrm{PhD}$ degree in educational curriculum from Universiti Sains Malaysia in 2010. Since January 2011, she has been with Faculty of Technical and Vocational Education, Universiti Tun Hussein Onn Malaysia as a senior lecturer.

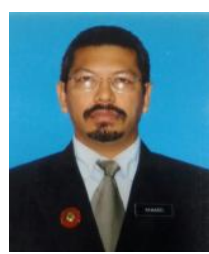

Ahmad Dollah received the M.Ed in technical education (instructional design and technology) from Universiti Tun Hussein Onn Malaysia in 2015. He has been with Kuala Kangsar Vocational Collage as a lecturer.

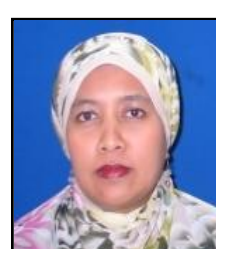

Yusmarwati Yusof received the $\mathrm{PhD}$ degree in education from University of East London in 2013 Since January 2011, she has been with Faculty of Technical and Vocational Education, Universiti Tun Hussein Onn Malaysia as a senior lecturer.

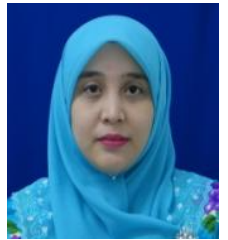

Nurfirdawati Muhammad Hanafi received the PhD degree in education (assessment) from Universit Pendidikan Sultan Idris in 2016. Since January 2011, she has been with Faculty of Technical and Vocational Education, Universiti Tun Hussein Onn Malaysia as a lecturer.

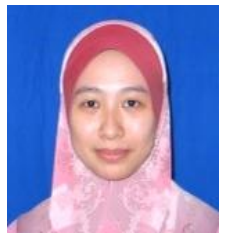

Nur Sofurah Mohd Faiz received the PhD degree in education from University of South Australia in 2014. Since January 2011, she has been with Faculty of Technical and Vocational Education, Universiti Tun Hussein Onn Malaysia as a senior lecturer. 